Myth and Reality

in

Late-Eighteenth-Century British Politics and Other Papers 
The End of North's Ministry, 1780-1 782 (1958)

Wilkes, Wyvill and Reform (1962)

Crisis of Empire, Great Britain and the American Colonies, I 754-1 783 (1966)

Essays in Modern History (Editor) (1968) 


\section{Myth and Reality}

$2 n$

Late-Eighteenth-Century British Politics and Other Papers

\section{IAN R. CHRISTIE}

Professor of Modern British History,

University College, London

UNIVERSITY OF CALIFORNIA PRESS Berkeley and Los Angeles 1970 
University of California Press Berkeley and Los Angeles, California

SBN 520-01673-4 Library of Congress Catalog Card Number: 73-104105

(C) Ian R. Christie 1970

Printed in Great Britain 